\title{
Bio-energy utilization through thermo efficient biomass cook stove for sustainable rural households
}

\begin{abstract}
The thermo efficient biomass cook stove was designed using scientific principles, to assist better combustion and heat transfer, for improving efficiency performance. The goal of a development of a thermo efficient biomass cook stove was to improve upon the shortcomings of the existing improved cook stoves and traditional stoves, while still ensuring lower cost and ease of use. The thermo efficient biomass cook stove was designed and developed in Department of Unconventional Energy Sources and Electrical Engineering, Dr. Panjabrao Deshmukh Krishi Vidyapeeth, Akola (MS). The performance of the cook stove was evaluated viz., fuel burning rate, power output rating, thermal efficiency and carbon monoxide concentration in laboratory and actual cooking test at user's site. The thermal efficiency of the thermo efficient biomass cook stove was found to be $31.34 \%$, which was $20.56 \%$ higher than traditional biomass mud cook stove. It saved 39\% cooking time over a traditional biomass cook stove. The CO concentration in flue gas emit by the thermo efficient cook stove was found to be $2.97 \mathrm{~g} / \mathrm{MJ}$, whereas, the $\mathrm{CO}$ concentration was found to be $73.15 \%$ higher in traditional biomass mud stove cook stove than that of the thermo efficient cook stove. The cook stove is a relatively clean burning device, fuel efficient and easy to operate. User friendly and low cost thermo efficient biomass cook stove is recommended for cooking in rural households using cotton stalk (bioenergy) as fuel. From the study, it reveals that use of thermo efficient cook stove would be perspective for rural households over the conventional cook stove.
\end{abstract}

Keywords: bio-energy, cotton stalk, thermo-efficient, thermal efficiency, GHG, RTD, MNRE
Volume 3 Issue 3 - 2017

\author{
AK Kamble, Krishi Vidyapeeth PD \\ College of Agricultural Engineering \& Technology, India
}

Correspondence: AK Kamble, Assistant Scientist, All India Coordinated Research Project on Energy in Agriculture and Agro-based Industries, College of Agricultural Engineering \& Technology, Akola (MS)-444 104, India,

Email anilkumar_kamble@hotmail.com

Received: October 22, 2016 | Published: June 23, 2017

\section{Introduction}

Biomass (bio-energy) has a very high potential as a renewable energy resource because of its reliability and availability everywhere around the globe. It is the fourth highest primary energy resource in the world after oil, coal, and gas, contributing about $10.6 \%$ of the global primary energy supply. Globally, around 2.6 billion people 40 per cent of the world's population still rely on traditional biomass to meet their household cooking energy requirements. Also, nearly 1.3 billion people remain without access to electricity and 2.6 billion still do not have access to clean cooking account for two-thirds of those without electricity and in just three countries, India China, and Bangladesh which account for more than half of those without clean cooking facilities. Almost 80 to $90 \%$ of the energy used in rural household is for cooking and water heating, of which 75 to $95 \%$ of the energy is from wood and charcoal. An estimated 826 million Indians depend on simple cook stoves that burn solid fuel, mainly fuel wood or coal. ${ }^{1,2}$ To mitigate indoor air pollution and to get more efficient technology for cooking have been remain one of the major challenges for researcher. Indoor smoke from solid fuels is the tenth leading cause of avoidable death worldwide. It is the second-most important environmental cause of disease after contaminated water borne diseases. It has been found that every year 4.3 million people die prematurely from illness attributed to the household air pollution caused by the inefficient use of solid fuels. It is also estimated that three to four lakh people die of indoor air pollution in India every year. ${ }^{3}$

Approximately $70 \%$ of the population of India live in rural areas where biomass are primarily utilized for meeting the cooking and heating requirements through open firing, traditional stoves and having very low efficiencies, about $10 \%$. Traditional biomass stoves cause significant greenhouse gas (GHG) emissions due to formation of products of incomplete combustion. Indoor air pollution is a major attributable factor for ill health in rural India. As per Ministry of Statistical and Programme Implementation, National Survey Office, Energy Sources of Indian households for cooking and lighting, 201112 , the rural households mostly used firewood \& chips as primary source of energy for cooking. At all India level, firewood \& chips were used by more than two-third $(67.3 \%)$ of rural households, followed by LPG, which was used by $15.0 \%$ households. Only $9.6 \%$ and $1.1 \%$ of the rural households used dung cake and coke and coal, respectively as primary source. The remaining $4.9 \%$ households used other sources, i.e. biogas, charcoal, electricity and others. $1.3 \%$ rural households did not have any arrangement for cooking. ${ }^{4}$ The cotton is cultivated by more than 10.0 million farmers in 12.7 million hectares in India. In India and Maharashtra cotton is the major principal crop and covers $12.70 \mathrm{Mha}$ and $4.2 \mathrm{Mha}$, respectively and produced $38.1 \mathrm{MT}$ and 12.6MT cotton stalks in India and Maharashtra, respectively. ${ }^{1}$ The cotton stalks are available with farmers at their farms. Considering the potential of cotton stalks and its availability in rural village, the stalks can be used as fuel for cook stove. There are many improved stoves are available but these are operated on wood fuel or briquettes and these are top fuel feeding. In this study the attempt has been made to develop thermo efficient biomass cook stove to operate on cotton crop residue (bioenergy) for sustainable rural households.

\section{Materials and methods}

The thermo efficient crop residue based biomass cook stove was developed in Department of Unconventional Energy Sources and 
Electrical Engineering, Dr. PDKV, Akola in 2015-16. The photograph and an isometric view of the developed cook stove are shown in Figure 1. In experimental study cotton stalk was collected from University field. The selected cotton stalks were dried in oven at $110^{\circ} \mathrm{C}$ to bring about $4-8 \%$ moisture content. In present study, cotton stalks fuel was selected as it is available with the farmers at their own farm. From the proximate analysis of the selected cotton stalks showed very low ash content, highest carbon content and low sulphur content. The cookstove performance tests had been performed as per Indian standard 13152: Part 1:1991 and modified draft December 2012.5 The complete experimental set up for performance evaluation of thermo efficient cook stove is shown in Figure 2. The various instruments viz., KANE 940 flue gas analyzer, infra red thermometer, temperature indicator, thermocouples (RTD), and weighing balance were used for evaluation of thermo efficient cook stove. A flue gas hand held analyzer of model KANE 940 was used for measuring the concentration of carbon monoxide present in flue gas. The flue gas velocity was measured by anemometer-vane probe of model AM 4201 at the out let of the hood for determination of flue gas flow rate. The flue gas flow rate was found out by the observations of flue gas velocity, cross sectional area of opening of hood and flue gas density. ${ }^{6,7}$ The fuel consumption rate was found out with reference to the BIS standard to determine the fuel burning rate per hour. To determine burning rate, the cook stove's combustion chamber was filled up to $3 / 4$ of the height of cook stove as recommended by BIS procedure. Initial and final weight of the cook-stove with weighed test fuel was measured before lighting the fuel. ${ }^{8,9}$ The further method and steps were adopted as per BIS testing norms and the fuel consumption rate was determined. On the basis of fuel consumption rate the heat input per hour was estimated using the following equation.

$$
\text { Heatinput, } \mathrm{kcal} / \mathrm{kg}=\left(M_{1}-M_{2}\right) X C V
$$

Where,

\section{$M_{1}$ - Initial mass of cook stove with test fuel, $\mathrm{kg}$}

$\mathrm{M}_{2}$ - Mass of cook stove with fuel residue after burning the test fuel for half an hour, $\mathrm{kg}$

\section{CV- Calorific value of fuel, $\mathrm{kcal} / \mathrm{kg}$}

The power output rating of cook stove is a measure of total useful energy produced during one hour by the fuel. ${ }^{10}$ It was calculated as follows.

$$
\text { Poweroutputrating }(P o), k W / h=F x C V x \eta x 860
$$

\section{Where,}

\section{Po-Power output, kWh}

F- Fuel consumption rate of cook stove, $\mathrm{kg} / \mathrm{h}$

\section{CV-Calorific value of fuel, $\mathrm{kcal} / \mathrm{kg}$}

$\eta$-Thermal efficiency of the cook stove, $\%$

The thermal efficiency of a cook stove is usually defined as the ratio of heat utilized to the heat theoretically produced by complete combustion of a given quantity of fuel. The thermal efficiency is the significant parameter to find out performance of the stove. Water boiling test was performed on cook stove. The constant heat output method was used for calculating the thermal efficiency of the cook stove. In this method, known quantity of water was heated in a pot on the cook stove till it attained a desired temperature. The heating temperature of the water was about $96^{\circ} \mathrm{C}$. At this temperature it was replaced by another pot with the same quantity of water at ambient temperature. The process was repeated till the completion of the combustion process. The thermal efficiency of the stove was calculated as per Indian Standard 13152: Part 1. ${ }^{5}$ It is expressed and calculated by the following equations.

$$
\begin{aligned}
& \text { Thermal Efficiency, } \%=\frac{\text { Heatutilized }}{\text { Heat produced }} \times 100 \\
& \text { Heatutilized }=(n-1) x(W x 0.896+w) x\left(t_{2}-t_{1}\right)+(W x 0.896+w) x\left(t_{3}-t_{1}\right)
\end{aligned}
$$

Heat produced $=m x C V$

Where,

m-Mass of fuel used, $\mathrm{kg}$

CV-Calorific value of fuel, $\mathrm{kcal} / \mathrm{kg}$
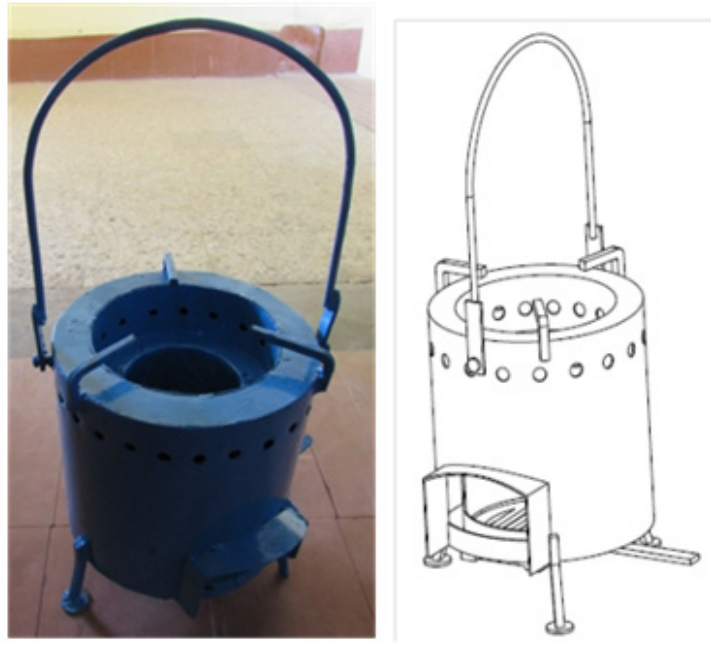

Figure I Photograph and isometric view of thermo efficient biomass cook stove.

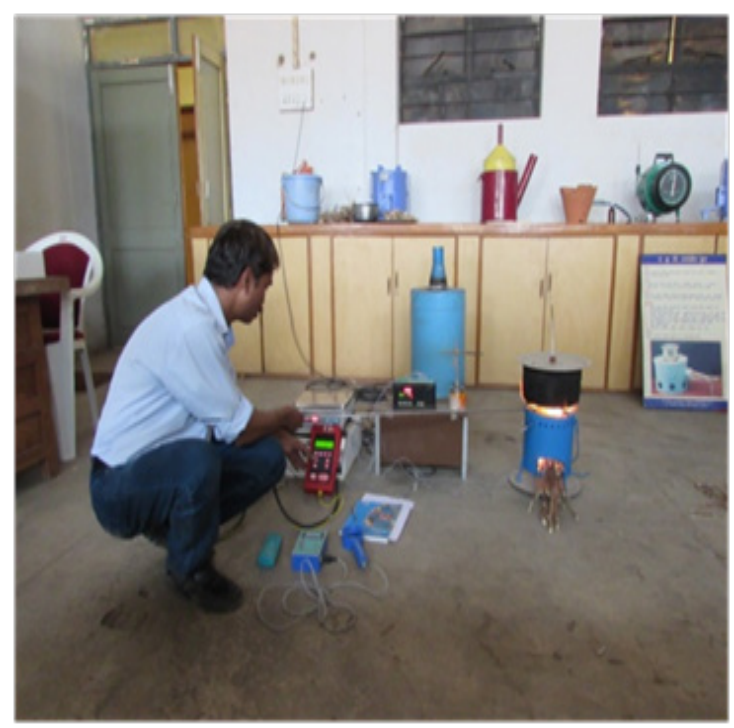

Figure 2 Complete set up for evaluation of thermo-efficient cook stove. 


\section{Results and discussion}

The fuel burning rate of the cook-stove was performed as per BIS standard and the results are shown in Table 4. The fuel consumption rate was found to be $1.089 \mathrm{~kg} / \mathrm{h}$. The power output rating was calculated and it was found to be $1.513 \mathrm{~kW}$. However, the fuel consumption rate of PDKV updraft wood stove, SPRERI and traditional mud stove Table I Fuel burning rate and power output rating cook stove was found to be $1.172,1.138$ and $1.264 \mathrm{~kg} / \mathrm{h}$, respectively. The power output rating of traditional mud stove, PDKV updraft wood stove, SPRERI cook stove was found to be 1.194, 1.907 and $0.683 \mathrm{~kW}$, respectively. It seems from Table 1 that fuel requirement was comparatively less than the existing cook stove and traditional cook stove

\begin{tabular}{llllll}
\hline Sr. no & Particulars & $\begin{array}{l}\text { Thermo- efficient } \\
\text { cook stove }\end{array}$ & $\begin{array}{l}\text { PDKV wood } \\
\text { stove }\end{array}$ & $\begin{array}{l}\text { SPRERI cook } \\
\text { stove }\end{array}$ & $\begin{array}{l}\text { Traditional } \\
\text { cook stove }\end{array}$ \\
\hline I & Fuel burning rate, $\mathrm{kg} / \mathrm{h}$ & 1.089 & 1.172 & 1.138 & 1.264 \\
2 & Power rating, $\mathrm{kW}$ & 1.513 & 1.194 & 1.907 & 0.683
\end{tabular}

\section{Thermal efficiency of stove}

The thermal efficiency of the agricultural residue based cook stove was worked out by using cotton stalks as fuel and results are represented in Table 2. It was observed that the average thermal efficiency of the cook stove was found to be $31.34 \%$. The thermal efficiency of the other stoves were also determined and compared with thermo efficient cook stove and the results are shown in Table 3. It is seen from the Table 3 that the thermal efficiency of the thermo efficient cook stove was found to be higher than that of the existing cook stove viz., PDKV updraft wood stove, SPRERI and traditional mud stove cook stove by $13.38,8.37$ and $20.56 \%$, respectively. The increase in thermal efficiency of the thermo efficient cook stove could be due to improved heat transfer to the pot by the cook stove and thus heat produced was effectively utilized than any other stove tested in the laboratory. The higher thermal efficiency of thermo efficient cook stove was due to the minimal heat losses and also the higher burning rate of fuel in others cooks stoves as well in traditional mud stove. The Ministry of New and Renewable Energy (MNRE), New Delhi, reported that the highest thermal efficiency of domestic cook stove of top feeding arrangement is $33.44 \%$ using wood as fuel, whereas, the developed thermo efficient cook stove with side fuel feeding arrangement had $31.34 \%$. In side feeding cook stove continuous fuel feeding is possible whereas, in top feeding cook stove every time cooking pot has to be removed for fuel feeding.

\section{CO concentration measurements}

Due to improper design of combustion zone and low thermal efficiency, it emits gaseous pollutants like CO. Such emissions have a serious health consequence on household members especially women involved in the cooking and on young children who spends time around their mother while playing. The CO concentration in flue gas emit by the thermo efficient cook stove was found to be $2.97 \mathrm{~g} /$ MJ, whereas, the CO concentration was found to be 18.63, 5.41 and $73.15 \%$ higher in PDKV updraft wood stove, SPRERI and traditional mud stove cook stove, respectively than that of the thermo efficient cook stove (Table 4). As per Indian standard the CO concentration should not exceed 3.5g/MJ heat delivery.

\section{Cooking test of thermo efficient cook stove}

The actual cooking test of the thermo efficient cook stove was taken in villages viz., Dagadparwa, Yeota and Kurankhed of Akola District (Figure 3). The detail study of preparation of food items prepared at the house of Mrs. Bebinanda Sanatan Tayade, At Yeota, Tq. Distt. Akola are given in the following Table 5. ${ }^{11}$ The total time requirement for preparation of meal for five adult's family members by using thermo efficient cook stove ${ }^{12}$ was worked out to be $52.5 \mathrm{~min}$ and the fuel requirement was $998 \mathrm{~kg}$. The comparative cooking test of various stove were also taken and given in Table 6 .

Table 2 Thermal efficiency of thermo efficient natural draft biomass cook stove

\begin{tabular}{|c|c|c|c|c|}
\hline \multirow{2}{*}{$\begin{array}{l}\text { S. } \\
\text { No }\end{array}$} & \multirow{2}{*}{ Particulars } & \multicolumn{3}{|l|}{ Tests } \\
\hline & & TI & T2 & T3 \\
\hline I & $\begin{array}{l}\text { Calorific value of cotton } \\
\text { stalk biomass, } \mathrm{kcal} / \mathrm{kg}\end{array}$ & 3757.5 & 3757.5 & 3757.5 \\
\hline 2 & $\begin{array}{l}\text { Ambient air temperature, } \\
O C\end{array}$ & 33.8 & 34.6 & 31.2 \\
\hline 3 & $\begin{array}{l}\text { Quantity of water taken in } \\
\text { pot for heating }(m), \mathrm{kg}\end{array}$ & 4 & 4 & 4 \\
\hline 4 & $\begin{array}{l}\text { Initial temperature of water } \\
(\mathrm{Tw}), 0 \mathrm{C}\end{array}$ & 26.1 & 26 & 26.3 \\
\hline 5 & $\begin{array}{l}\text { Water heating temperature } \\
(\mathrm{T} x), 0 \mathrm{C}\end{array}$ & 96 & 96 & 96 \\
\hline 6 & $\begin{array}{l}\text { Highest temperature } \\
\text { attainted by the last pot } \\
\text { (Tb),0C }\end{array}$ & 46 & 41 & 51 \\
\hline 7 & $\begin{array}{l}\text { Total quantity of water } \\
\text { heated }(\mathrm{Mt}), \mathrm{kg}\end{array}$ & 32 & 32 & 32 \\
\hline 8 & $\begin{array}{l}\text { Total quantity of water } \\
\text { heated at } 960 \mathrm{C} \text { (excluding } \\
\text { quantity of water from last } \\
\text { pot (M), } \mathrm{kg}\end{array}$ & 28 & 28 & 28 \\
\hline 9 & $\begin{array}{l}\text { Quantity of water heated } \\
\text { in last pot }(\mathrm{m}), \mathrm{Kg}\end{array}$ & 4 & 4 & 4 \\
\hline 10 & $\begin{array}{l}\text { Total amount of water } \\
\text { evaporated (MI), kg }\end{array}$ & 0.4829 & 0.5154 & 0.427 \\
\hline 11 & $\begin{array}{l}\text { Specific heat of water }\left(C_{P}\right) \text {, } \\
\mathrm{kcal} / \mathrm{kg}\end{array}$ & 1 & 1 & 1 \\
\hline 12 & $\begin{array}{l}\text { Latent heat of vaporization } \\
(\mathrm{H}), \mathrm{kcal} / \mathrm{kg}\end{array}$ & 586.436 & 586.436 & 586.436 \\
\hline 13 & $\begin{array}{l}\text { Quantity of biomass used, } \\
\text { (W), kg }\end{array}$ & 2 & 2 & 2 \\
\hline 14 & Thermal efficiency, \% & 31.25 & 31.56 & 31.19 \\
\hline 15 & $\begin{array}{l}\text { Average thermal efficiency, } \\
\%\end{array}$ & 31.34 & & \\
\hline
\end{tabular}



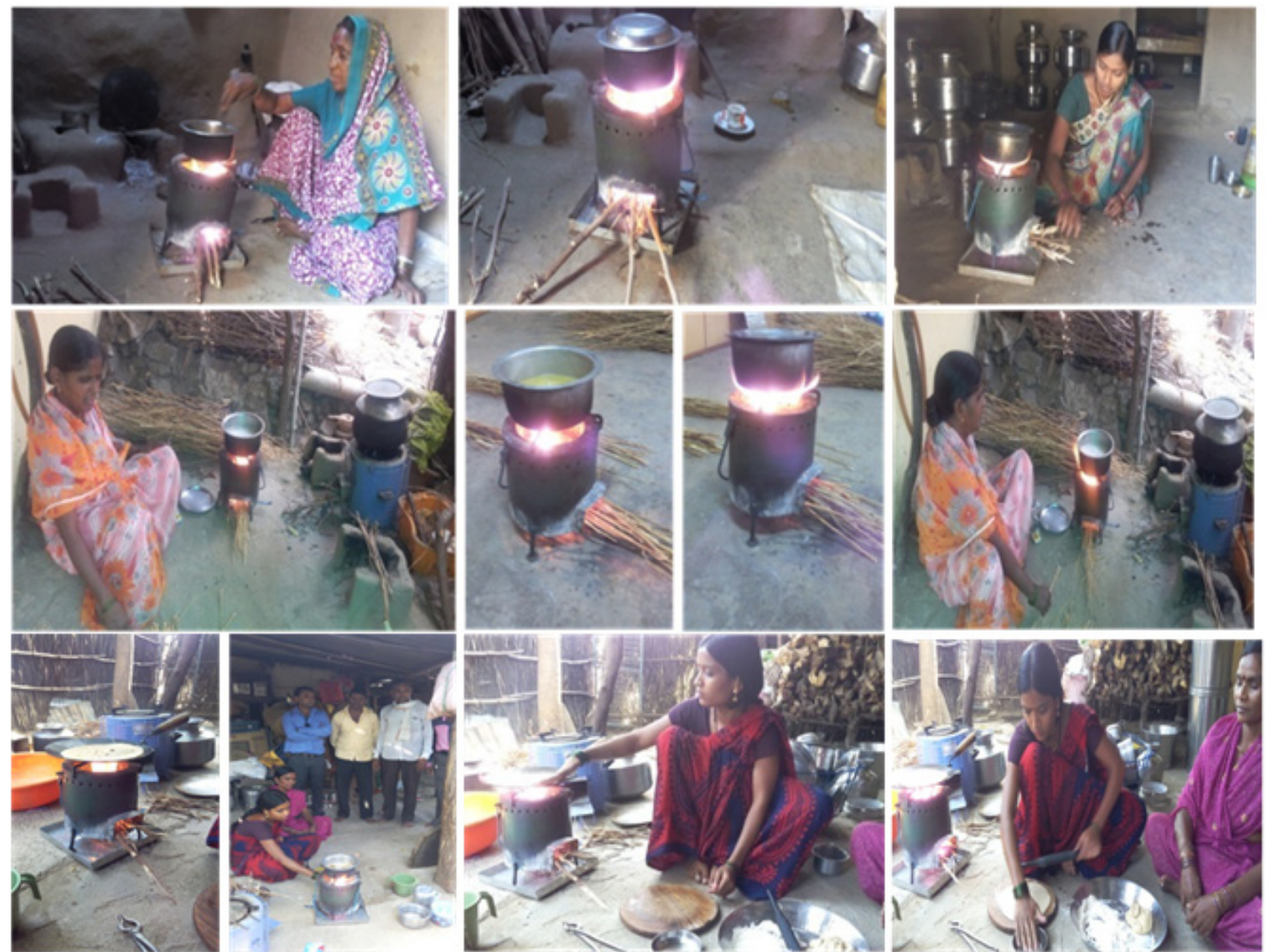

Figure 3 Cooking test of thermo efficient cook stove at Dagadparva, Kurankheda and Yeota Distt, Akola.

Table 3 Comparison of thermal efficiency of different cook stove

\begin{tabular}{lllll}
\hline Particulars & $\begin{array}{l}\text { Thermo- efficient cook } \\
\text { stove }\end{array}$ & $\begin{array}{l}\text { PDKV wood } \\
\text { stove }\end{array}$ & $\begin{array}{l}\text { SPRERI cook } \\
\text { stove }\end{array}$ & $\begin{array}{l}\text { Traditional single pot cook } \\
\text { stove }\end{array}$ \\
\hline Thermal efficiency, \% & 31.34 & 20.93 & 25.94 & 10.78 \\
\hline
\end{tabular}

Table $4 \mathrm{CO}$ concentration in flue gas

\begin{tabular}{llllll}
\hline S. No & Particulars & $\begin{array}{l}\text { Thermo- efficient cook } \\
\text { stove }\end{array}$ & $\begin{array}{l}\text { PDKV wood } \\
\text { stove }\end{array}$ & $\begin{array}{l}\text { SPRERI cook } \\
\text { stove }\end{array}$ & $\begin{array}{l}\text { Traditional cook } \\
\text { stove }\end{array}$ \\
\hline I & $\begin{array}{l}\text { CO concentration, } \\
\text { g/MJ }\end{array}$ & 2.97 & 3.65 & 3.14 & 11.06 \\
\hline
\end{tabular}

Table 5 Preparation of meal using thermo efficient cook stove

\begin{tabular}{lllll}
\hline S. No & Particulars & Wt. of material, gm/ml & Time required, $\mathbf{m i n}$ & Fuel required, gm \\
\hline I & Tea & 250 & 5.5 & 117 \\
2 & Chapati & 500 & 23.5 & 469 \\
3 & Curry & 525 & 12.5 & 214 \\
4 & Rice & 125 & 11 & 198 \\
Total & & & 52.5 & 998 \\
\hline
\end{tabular}


Table 6 Comparative cooking test and cost of various cook stoves

\begin{tabular}{|c|c|c|c|c|c|}
\hline $\begin{array}{l}\text { S. } \\
\text { No }\end{array}$ & Particulars & $\begin{array}{l}\text { Thermo efficient cook } \\
\text { stove }\end{array}$ & $\begin{array}{l}\text { SPRERI cook } \\
\text { stove }\end{array}$ & $\begin{array}{l}\text { PDKV cook } \\
\text { stove }\end{array}$ & $\begin{array}{l}\text { Single pot mud } \\
\text { stove }\end{array}$ \\
\hline I & Wt. of rice taken for cooking, gm & 250 & 250 & 250 & 250 \\
\hline 2 & $\begin{array}{l}\text { Time required for cooking rice, } \\
\min \end{array}$ & II & 18 & 16 & 18 \\
\hline 3 & Cost of stove, Rs. & 700 & 1400 & 2000 & - \\
\hline
\end{tabular}

The advantages of the thermo efficient cook stove over the traditional mud cook stove are

i. Higher thermal efficiency of the cook stove

ii. Reduction in smoke and healthier environment for women and children

iii. Reduces drudgery of women for collection of fuel wood from forest

iv. Reduced deforestation due to use of cotton stalks available with the farmers

v. Reduction in cooking time by $39 \%$

vi. Less exposure of women to kitchen smoke

vii. Less cost of fabrication of the stove (INR 700/-)

\section{Users feed back}

i. Emitted very less smoke

ii. No irritation to the eyes

iii. It is very easy to operate

iv. Continuous fuel feeding arrangement

v. Portable and it can move at any corner of the house

vi. It can be hang to the nail in the house after cooking.

vii. Ash collection tray facilitate for clean kitchen

\section{Conclusion}

The thermal efficiency of the thermo efficient biomass cook stove was found to be $31.34 \%$ and which was $20.56 \%$ higher than traditional biomass cook stove. It saved $39 \%$ cooking time over a traditional biomass cook stove. The $\mathrm{CO}$ concentration in flue gas emitted by the thermo efficient cook stove was found to be $2.97 \mathrm{~g} / \mathrm{MJ}$, whereas, the CO concentration was found to be $18.63,5.41$, and $73.15 \%$ higher in PDKV updraft wood stove, SPRERI and traditional mud stove cook stove, respectively than that of the thermo efficient cook stove. The cost of thermo efficient cook stove is very less as compared to the any other existing cook stoves. The cook stove is a relatively clean burning device, fuel efficient, low cost and user friendly.

\section{Conflict of interest}

The author declares no conflict of interest.

\section{References}

1. Anonymous. Future potential of biomass energy in India. Bioenergy India, India: Ministry of New and Renewable Energy; 2011. p. 6-11.

2. Anonymous. Energy Sources of Indian Households for Cooking and Lighting. 2011-12 Ministry of Statistics and Programme Implementation, India; 2012. p. 12-22.

3. Tripathi AK. Renewable energy for rural areas. Akshay Urja. 2014;8(2):28-32.

4. Anonymous. World Energy Outlook. France: International Energy Agency; 2012. p. 6-7.

5. Kshirsagar MP, Kalamkar VR. A comprehensive review on biomass cook stoves and a systematic approach for modern cook stove design. Renewable and Sustainable Energy Reviews. 2014;30:580-603.

6. Harshika K, Chandra A, Kaushik SC. Comparative study on emissions from traditional and improved biomass cook stoves used in India. International Journal for Research in Applied Science and Engineering Technology. 2014;2(8):249-257.

7. Motghare KA, Rathod AP, Waghmare SS, et al. Performance evaluation and heat transfer studies on biomass gasifier cook stove. International Journal of Application or Innovation in Engineering \& and Management. 2015;4:47-63.

8. Panwar NL, Rathore NS. Design and performance evaluation of a $5 \mathrm{~kW}$ producer gas stove. Biomass and Bio-energy. 2008;32(12):1349-1352.

9. Venkataraman C, Sagar AD, Habib G, et al. The Indian National Initiative for advanced biomass cooks stoves: The benefits of clean combustion. Energy for Sustainable Development. 2010;14(2):63-72.

10. Bansal M, Saini RP, Khatod DK. Development of cooking sector in rural areas in India. Renewable and Sustainable Energy Reviews. 2013;17(3):44-53.

11. Muralidharan V, Sussan TE, Limaye S, et al. Field testing of alternative cook stove performance in a rural setting of western India. Int J Environ Res Public Health. 2015;12(3):1773-1787.

12. Powar R, Bandgar PS, Kadu P. clean energy from cotton stalk exercise of cook stove. International Journal of Emerging Technology and Advanced Engineering. 2014;4(7):469-474.

\section{Acknowledgements}

None. 